\title{
ВІТАННЯ 3 ЮВІЛЕЄМ ВИДАТНОГО КЕРІВНИКА, ВЧЕНОГО, ПЕДАГОГА УКРАЇНСЬКОЇ ВИДАВНИЧО-ПОЛІГРАФІЧНОЇ ГАЛУЗІ
}

Розум людський володіє трьома ключами, що відкривають все:
цифрою, буквою, нотою. Знати, думати, мріяти. Все в цьому. В. Гюго

Середина серпня цього року ознаменована 85-літнім ювілеєм Розума Олега Федоровича професіонала в усіх напрямах українського друкарства: виробництві, науці, освіті.

Олег Федорович народився в Києві 16 серпня 1934 року. Фахову освіту здобув у 1958 р. на інженерно-технологічному факультеті Українського поліграфічного інституту ім. Івана Федорова (УПІ, Львів). У 1958-1969 рр. працював у видавництві «Радянська Україна» (нині - «Преса України») на посадах інженера-технолога, начальника цеху, головного технолога, заступника головного інженера філії.

Впродовж 1969-1970 рр. Олег Федорович починає наукову діяльність спочатку як завідувач лабораторії Всесоюзного науково-дослідного та проектного інституту хімічної промисловості (ВНДІ Хімпроект), а у 1970-1975 рр. головним інженером Київської філії Державного проектного і науково-дослідного інституту поліграфічної промисловості (ДІПРОНДІ Поліграф), де очолював робочу групу з розробки проектів як вітчизняних, так і закордонних поліграфічних підприємств.

у 1973 р. Олег Федорович під керівництвом завідувача кафедри технології поліграфічного виробництва УПІ ім. Івана Федорова Б. В. Коваленка захистив дисертаційну роботу «Исследование фи-

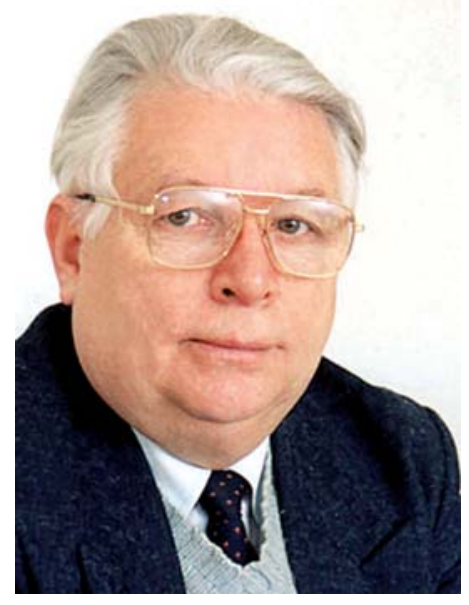

зико-механических и физико-химических свойств фотополимерных печатных форм» (Московський поліграфічний інститут) на здобуття наукового ступеня кандидата технічних наук. Знаменною є приналежність Олега Федоровича до вітчизняної наукової школи технології поліграфічного виробництва під керівництвом професора Б. В. Коваленка, адже плідна робота учасників цієї школи: Е. Т. Лазаренка й В. А. Кравчука та їх учнів у Львові, а О. Ф. Розума з його учнями в Києві докорінно змінила та модернізувала технологію формних і друкарських процесів, й в цілому інтенсифікувала виробництво поліграфічної продукції та суміжних галузей промисловості.

З 1975 р. починається освітянська діяльність Олега Федоровича у Київському вечірньому факультеті УПІ ім. Івана Федорова, де він

(C) 2019 p. 
спочатку працює старшим викладачем, згодом - доцентом кафедри технології та економіки поліграфічного виробництва (з 1979 р.), впродовж 1979-1987 рр. - декан Київського вечірнього факультету УПІ ім. Івана Федорова, а 19892003 рр. - завідував кафедрою технології поліграфічного виробництва (ТПВ) Видавничо-поліграфічного факультету Національного технічного університету України «Київський політехнічний інститут» (НТУУ «КП|»), з 2003 р. професор кафедри ТПВ Видавничо-поліграфічного інституту НТУУ «КП|» та член спеціалізованих вчених рад із захисту дисертацій, причому під керівництвом Олега Федоровича успішно захистили кандидатські дисертації чотири аспіранти (Л. І. Мартинюк, Т. Г. Осипова, Ю. Ф. Орлова, О. В. Зоренко). Протягом 1974-2004 рр. Олег Федорович незмінний голова правління Київського науковотехнічного товариства видавців, поліграфістів і організаторів книжкової торгівлі. Одночасно впродовж 1994-2002 рр. Олег Федорович головний редактор провідного науково-практичного часопису «Друкарство», член редакційних колегій, науковий редактор ряду наукових журналів та збірників, більшість з яких є послідовниками часопису «Друкарства» (на жаль, останнє число якого вийшло 2006 р.), одним з них є збірник наукових праць Видавничополіграфічного інституту (ВПІ) КПІ ім. Ігоря Сікорського «Технологія і техніка друкарства», який є фаховим виданням, що оприлюднює результати досягнень видавничополіграфічної справи та суміжних галузей виробництва.
Серед творчих доробок Олега Федоровича понад сто наукових та навчально-методичних праць: підручники, монографії, навчальні посібники, авторські свідоцтва на винаходи, патенти як одноосібні, так й у співавторстві. Причому письменна наукова праця Олега Федоровича продовжується й на заслуженому відпочинку, свідченням цього $€$ колективне видання у співавторстві з д-ром техн. наук, професором, завідувачем кафедри репрографії ВПІ КПІ ім. Ігоря Сікорського О. М. Величко та канд. техн. наук О. В. Мельниковим наукового посібника «Таємниці друкарства: минуле, сучасне, майбутнє» (Львів: Українська академія друкарства, 2012, 280 с.), що відображає розвиток видавничо-поліграфічної справи від перших наскельних піктограм до новітніх технологій і техніки друкарства на основі інтелектуальних комп'ютерних систем, нанотехнологій та робототехніки.

Варто зазначити, що плідну освітянську та наукову працю Олега Федоровича відзначено вітчизняними та зарубіжними нагородами.

Вельмишановний Олеже Федоровичу!

Від всієї душі прийміть щирі й теплі поздоровлення з ювілеєм!

Зичимо Вам міцного здоров'я, духовних і фізичних сил, невичерпної життєвої наснаги, тепла та затишку у Вашій оселі!

Нехай роки залишають тільки світлі спогади, а майбутнє дарує ще багато щасливих літ, сповнених радості, добра, надії! 